\title{
Penerapan Model Pembelajaran Kooperatif Tipe Jigsaw untuk Meningkatkan Motivasi dan Hasil Belajar Pada Materi Pencemaran dan Kerusakan Lingkungan Pada Kelas VII.1 di SMP Negeri 13 Pekanbaru
}

\author{
Rosyidah * \\ * SMP Negeri 13 Pekanbaru
}

\begin{tabular}{l} 
INFO ARTIKEL \\
\hline Riwayat Artikel: \\
Diterima: 6 Maret 2018 \\
Disetujui: 10 Juni 2018 \\
\hline
\end{tabular}

\section{Kata kunci:}

Kooperatif Tipe Jigsaw

Pencemaran dan Kerusakan Lingkungan

Motivasi dan Hasil Belajar

\author{
Alamat Korespondensi: \\ Rosyidah, \\ SMP Negeri 13 Pekanbaru \\ Jl. Ronggowarsito I No. 15 Pekanbaru \\ E-mail: rosyidah@gmail.com
} rencen

\begin{abstract}
ABSTRAK
Abstract: The background of this study is the low motivation and learning outcomes of class VII.1 SMP Negeri 13 Pekanbaru. This study aims to improve the motivation and learning outcomes of students of class VII.1 SMP Negeri 13 Pekanbaru through the application of the Jigsaw type cooperative learning model to the material of pollution and environmental damage. The study was conducted in 2 cycles and each cycle consisted of 2 meetings. The data obtained is in the form of final test data (post test) from each cycle, the results of observational data on affective aspects and the results of filling in the motivation questionnaire. Data analysis in this study was carried out qualitatively and quantitatively. Based on the research that has been done, it can be concluded that the application of the Jigsaw type cooperative learning method to class VII.1 students of SMP Negeri 13 Pekanbaru can increase motivation and learning outcomes in biological matter of pollution and environmental damage. Based on the analysis of research data, the acquisition of scores from questionnaires on student learning motivation was very high, from $63 \%$ to $84 \%$ in the very high category. Meanwhile for cognitive aspects of learning outcomes, the average score obtained in the first cycle was 68.75 with a percentage of $\mathrm{KKM}$ completeness of $37.50 \%$, increasing to 83.78 with a percentage of KKM completeness of $80 \%$ in cycle II. Whereas for affective learning outcomes also in accordance with the expected target of achievement, namely an increase in the high category. Where in the first cycle, $83 \%$ of students were in the high category and $17 \%$ in the medium category, while in the second cycle, $100 \%$ of the students were in the high category.
\end{abstract}

\section{LATAR BELAKANG}

Proses pembelajaran di dalam kelas merupakan suatu dunia komunikasi tersendiri di mana terjadi pertukaran pikiran antara guru dan siswa untuk mengembangkan suatu ide. Pembelajaran juga merupakan aspek kegiatan manusia yang kompleks, yang tidak sepenuhnya dapat dijelaskan. Pembelajaran secara sempit dapat diartikan sebagai produk interaksi berkelanjutan antara pengembangan dan pengalaman hidup. "Pembelajaran dalam makna kompleks adalah usaha sadar dari seorang guru untuk membelajarkan siswanya (mengarahkan interaksi siswa dengan sumber belajar lainnya) dalam rangka mencapai tujuan yang diharapkan” (Trianto, 2009). Salah satu cara pendidik untuk mencapai tujuan pembelajaran yaitu dengan menggunakan metode atau model pembelajaran sesuai dengan materi yang disampaikan. 
Berdasarkan hasil observasi penulis di SMP Negeri 13 Pekanbaru, terlihat bahwa proses pembelajaran dilakukan dengan metode ceramah dan tanya jawab sehingga siswa terlihat kurang aktif. Secara umum, ketika proses pembelajaran berlangsung di dalam kelas, siswa hanya menjawab pertanyaan jika diajukan oleh guru. Selain itu, siswa terlihat kurang termotivasi untuk mengikuti proses pembelajaran. Hal ini dapat dilihat dari tidak adanya inisiatif dari para siswa untuk bertanya kepada guru ketika guru memberikan waktu untuk bertanya. Selain itu, guru hanya menggunakan media power point tanpa media lain yang sesuai dengan materi yang diajarkan. Dalam pembelajaran biologi biasanya guru hanya memberi materi melalui slide atau melalui buku pegangan dengan metode ceramah yang diselingi tanya jawab. Guru belum bisa menerapkan metode dan media yang bervariasi sebagai alat bantu dalam proses pembelajaran dikarenakan guru tidak mempunyai waktu untuk menyiapkan media disebabkanoleh jadwal mengajar yang sangat padat. Dampak dari metode pembelajaran yang digunakan oleh guru dalam proses belajar mengajar ini, membuat siswa menjadi jenuh dan pasif serta membuat siswa tidak termotivasi untuk mempelajari pencemaran dan kerusakan lingkungan. Akibat dari motivasi yang rendah, ini mempengaruhi hasil belajar siswa. Motivasi siswa yang rendah tersebut dapat dilihat dari kegiatan-kegiatan yang dilakukan siswa yang tidak ada hubungannya dengan proses pembelajaran seperti melamun, mengantuk, mengobrol dan lain sebagainya. Dengan demikian, dapat dikatakan bahwa permasalahan pokoknya adalah bagaimana guru memilih metode dan tipe media pembelajaran yang tepat untuk melibatkan siswa dalam proses pembelajaran di kelas.

Materi pencemaran dan kerusakan lingkungan merupakan salah satu materi dalam pelajaran biologi dianggap mudah karena berkaitan dengan kehidupan sehari-hari. Namun berdasarkan rata -rata nilai hasil belajar siswa kelas VII.1 SMP Negeri 13 Pekanbaru tahun sebelumnya pada materi pencemaran dan kerusakan lingkungan hanya 64,29 dengan ketuntasan KKM sebesar 65\% siswa. Sementara 35\% siswa yang memperoleh nilai di bawah KKM yang ditentukan. Seperti yang telah kita ketahui bersama bahwa secara nasional pembelajaran dianggap tuntas/berhasil apabila ketercapaian KKM minimal $80 \%$ dari jumlah siswa. Dari data tersebut jelas bahwa hasil belajar siswa kelas VII pada mata pelajaran pencemaran dan kerusakan lingkungan masih perlu ditingkatkan.

Salah satu cara untuk mengukur keberhasilan suatu pembelajaran yaitu dengan tercapainya indikator dan tujuan pembelajaran yang telah disusun. Indikator keberhasilan belajar adalah tercapainya tujuan pembelajaran oleh siswa, sedangkan tujuan pembelajaran akan tercapai apabila kegiatan belajar siswa dapat dioptimalkan sesuai dengan kemampuan yang dimiliki oleh masing-masing siswa. Ini berarti jika motivasi belajar siswa dapat ditingkatkan, maka hasil belajar sebagai tujuan pembelajaran dapat tercapai dengan baik, sesuai dengan apa yang diharapkan. Atas dasar situasi tersebut, maka perlu dilakukan perbaikan pada proses pembelajaran Biologi untuk kelas VII.1 SMP Negeri 13 Pekanbaru, agar motivasi dan hasil belajar siswa dapat ditingkatkan. Salah satu metode yang dapat diterapkan untuk mengembangkan hasil dan motivasi belajar adalah dengan pembelajaran koopertif tipe Jigsaw.

Pembelajaran kooperatif model Jigsaw dikembangkan oleh Elliot Aronson dari Universitas Texas USA yang kemudian diadaptasi oleh Slavin di Universitas John Hopkins. Pembelajaran kooperatif tipe Jigsaw adalah suatu tipe pembelajaran kooperatif yang terdiri dari beberapa anggota dalam satu kelompok dan bertanggung jawab atas penguasaan bagian materi belajar dan mampu mengajarkan materi tersebut kepada anggota lain dalam kelompoknya. Model pembelajaran kooperatif tipe Jigsaw merupakan model pembelajaran kooperatif dimana siswa belajar dalam kelompok kecil yang terdiri dari 4-6 orang secara heterogen dan bekerjasama saling ketergantungan yang positif dan bertanggung jawab atas keberhasilan bagian materi yang harus dipelajari dan menyampaikan materi tersebut kepada anggota kelompok yang lain.

Pada model pembelajaran kooperatif tipe Jigsaw, terdapat dua kelompok yaitu kelompok asal dan kelompok ahli. Kelompok asal yaitu kelompok utama siswa yang beranggotakan siswa dengan kemampuan, asal, dan latar belakang keluarga yang beragam. Kelompok asal merupakan gabungan dari beberapa anggota kelompok ahli. Sedangkan kelompok ahli yaitu kelompok siswa yang terdiri dari anggota kelompok asal yang berbeda yang ditugaskan untuk mempelajari dan mendalami topik tertentu dan menyelesaikan tugas-tugas yang berhubungan dengan topiknya yang untuk kemudian dijelaskan kepada anggota kelompok asal. Menurut 
102 Instructional Development Journal (IDJ), Vol. 1, No. 2, Desember 2018, Hal. 100-106

Wena (2009) secara umum penerapan model pembelajaran kooperatif tipe jigsaw di kelas adalah sebagai berikut: Kelas dibagi dalam beberapa kelompok. Tiap kelompok siswa terdiri dari 4-6 orang yang bersifat heterogen, baik dari segi kemampuan, jenis kelamin, budaya dan sebagainya: 1) Tiap kelompok diberi bahan ajar dan tugas-tugas pembelajaran yang harus dikerjakan; 2) Dari masing-masing kelompok diambil seorang untuk membentuk kelompok baru (kelompok pakar) dengan membahas tugas yang sama. Dalam kelompok ini diadakan diskusi antara anggota kelompok pakar; 3) Anggota kelompok pakar kemudian kembali ke kelompok semula, untuk mengajari anggota kelompoknya. Dalam kelompok ini diadakan diskusi antara anggota kelompok; 4) Selama proses pembelajaran secara kelompok guru berperan sebagai fasilitator dan motivator; 5) Tiap minggu atau dua minggu guru melaksanakan evaluasi baik secara individual maupun kelompok untuk mengetahui kemajuan belajar siswa; dan 6) Bagi siswa dan kelompok siswa yang memperoleh nilai hasil belajar yang sempurna diberi penghargaan. Demikian pula jika semua kelompok memperoleh nilai hasil belajar yang sempurna maka wajib diberi penghargaan.

Menurut Johson dalam Lie (2002) bahwa "suasana belajar kooperatif tipe Jigsaw menghasilkan prestasi belajar yang lebih tinggi, hubungan yang lebih positif dan penyesuaian psikologi yang lebih baik daripada suasana belajar yang penuh persaingan". Selain itu, pembelajaran kooperatif tipe Jigsaw memiliki beberapa keunggulan antara lain: 1) Mengembangkan hubungan yang positif diantara siswa yang memiliki kemampuan berbeda; 2) Menerapkan bimbingan sesama teman; 3) Rasa saling menghargai meningkat; 4) Memperbaiki kehadiran; 5) Lebih bisa menerima perbedaan; 6) Pemahaman materi lebih mendalam; dan 7) Meningkatan motivasi belajar. Sedangkan beberapa kelebihan pembelajaran kooperatif tipe Jigsaw menurut Fathurrohman (2015) adalah sebagai berikut: 1) Siswa dapat bekerjasama dengan sesama siswa dalam suasana gotong royong; 2) Siswa mempunyai banyak kesempatan untuk mengolah informasi dan meningkatkan keterampilan berkomunikasi; 3) Bertanggung jawab atas penguasaan materi dan mampu mengajarkan materi tersebut kepada anggota lain dalam kelompoknya; dan 4) Meningkatkan rasa tanggung jawab siswa terhadap pembelajarannya sendiri dan juga pembelajaran orang lain.

Menurut Ardiyanto (2013) "pemberian pembelajaran kooperatif tipe Jigsaw akan mendorong siswa aktif dalam proses pembelajaran sehingga menghilangkan kejenuhan atau kebosanan seperti ketika pengajaran pada pembelajaran konvensional yang berpusat pada guru”. Strategi pembelajaran kooperatif tipe Jigsaw ini juga dapat meningkatkan pemahaman siswa terhadap materi pembelajaran sehingga dapat meningkatkan nilai prestasi belajar. Sementara itu, model pembelajaraan kooperatif tipe Jigsaw juga memiliki kelemahan yaitu: 1) Siswa yang aktif akan lebih mendominasi diskusi dan cenderung mengontrol jalannya diskusi; 2) Siswa yang memiliki kemampuan membaca dan berpikir rendah akan mengalami kesulitan untuk menjelaskan materi apabila ditunjuk sebagai tenaga ahli; 3) Siswa yang cerdas cenderung merasa bosan; dan 4) Siswa yang tidal terbiasa berkompetisi akan kesulitan untuk mengikuti proses pembelajaran.

Usaha-usaha yang dapat dilakukan oleh guru untuk mengatasi kelemahan-kelemahan tersebut diantaranya: 1) Guru harus menekankan agar anggota kelompok menyimak terlebih dahulu penjelasan dari anggota kelompok ahli. Kemudian baru mengajukan pertanyaan; 2) Guru harus memilih anggota kelompok ahli secara tepat, kemudian memonitor kinerja mereka dalam menjelaskan materi, agar materi dapat tersampaikan secara akurat apabila tidak mengerti; 3) Guru harus menciptakan suasana kelas yang menyenangkan agar siswa yang cerdas tertantang untuk mengikuti jalannya diskusi. Pemilihan metode pembelajaran kooperatif tipe Jigsaw dikarenakan model ini dapat membuat siswa lebih aktif sehingga pelajaran yang telah dipelajari menjadi lebih mudah dipahami. Selain itu, Jigsaw lebih difokuskan pada pembelajaran teman dalam kelompok atau teman sebaya, sehingga dapat meminimalisir kesenjangan tingkat kemampuan akademik tinggi untuk dapat membantu temannya yang memiliki kemampuan kurang, dan sebaliknya siswa yang memiliki kemampuan akademik rendah dapat belajar dari teman yang memiliki kemampuan akademik tinggi.

Berdasarkan permasalahan di atas, maka peneliti akan melakukan penelitian mengenai penerapan metodepembelajaran kooperatif tipe Jigsaw untuk meningkatkan motivasi dan hasil belajar siswa. Penelitian ini diberi judul: "Penerapan Model Pembelajaran Kooperatif Tipe Jigsaw Untuk Meningkatkan Motivasi dan 
Hasil Belajar Materi Pencemaran dan Kerusakan Lingkungan Pada Siswa Kelas VII.1 di SMP Negeri 13 Pekanbaru".

\section{METODE}

Penelitian ini menggunakan metode penelitian tindakan kelas (PTK). PTK merupakan suatu kegiatan penelitian yang dilakukan oleh pendidik/guru untuk memecahkan suatu masalah yang ada di dalam lingkungan sekolah baik yang menyangkut proses pembelajaran di dalam kelas maupun yang ada di luar kelas. Penelitian yang dilakukan merupakan penelitian deskriptif kuantitatif-kualitatif. "Penelitian tipe ini merupakan penelitian yang bertujuan untuk mendeskripsikan suatu keadaan atau segala sesuatu yang bisa dijelaskan baik dengan angka maupun dengan kata-kata" (Setyosari, $2010: 33$ ). Jenis penelitian ini memiliki tahapan, yaitu : (1) perencanaan tindakan (Planning), (2) pelaksanaan tindakan (Acting), (3) mengobservasi dan mengevaluasi proses hasil tindakan (Observation and evaluation), dan (4) Refleksi (Reflektion). Subyek dalam penelitian ini adalah siswa-siswi kelas VII.1 SMP Negeri 13 Pekanbaru yang terdiri dari 40 siswa. Obyek dalam penelitian ini adalah motivasi dan hasil belajar siswa pada pencemaran dan kerusakan lingkungan kelas VII.1 SMP Negeri 13 Pekanbaru.

Instrument pembelajaran terdiri dari silabus, rencana pelaksaan pembelajaran (RPP) dan kartu soal. Rencana pelaksanaan pembelajaran (RPP) dibagi menjadi dua siklus yaitu siklus I dan siklus II, dimana masing-masing siklus terbagi menjadi 2 kali pertemuan. Media yang digunakan dalam proses belajar mengajar pada penelitian ini yaitu media kartu soal. Instrument pengumpulan data yang digunakan dalam penelitian ini yaitu berupa test dan non-test. Dalam penelitian ini, analisis data dilakukan secara kuantitatif dan kualitatif. Analisis kuantitatif dilakukan dengan cara mengumpulkan data-data atau informasi yang diperoleh dari hasil pengamatan, lalu dianalisis secara kuantitatif. Analisis kuantitatif menggunakan rumus.

$$
N P=\frac{N k}{R} x 100 \%
$$

Keterangan:

$\mathrm{NP} \quad=$ Nilai dalam presentase

$\mathrm{NK} \quad=$ Nilai kumulatif

$\mathrm{R} \quad=$ Jumlah responden

Setelah data motivasi siswa diperoleh, peneliti dapat menyimpulkan berdasarkan target yang diinginkan. Dalam penelitian ini, peningkatan motivasi belajar siswa pada materi kerusakan dan pencemaran lingkungan dengan metode Jigsaw dikatakan berhasil apabila siswa dengan kategori skor tinggi $80 \%$. Kemudian, data-data yang diperoleh dari hasil pengamatan juga dianalisis secara kualitatif dilakukan dengan deskripsi kata-kata dari hasil pengamatan selama proses pembelajaran dengan menggunakan metode Jigsaw.

\section{HASIL DAN PEMBAHASAN}

\section{Motivasi Belajar}

Motivasi siswa diperoleh melalui lembar kuisioner yang telah dipersiapkan oleh peneliti. Untuk pengambilan data motivasi belajar siswa, peneliti membuat dua kuisioner yaitu kuisioner motivasi awal dan kuisioner motivasi akhir. Kuisioner motivasi awal diberikan kepada siswa pada pertemuan pertama siklus I sedangkan motivasi akhir pada pertemuan kedua siklus II. Kuisioner berisikan 20 soal campuran antara pernyataan positif dan pernyataan negatif dengan pilihan jawaban sangat setuju, setuju, tidak setuju dan sangat tidak setuju. Berdasarkan hasil analisa data pada siklus I untuk motivasi awal terdapat 25 siswa atau sebesar $62,50 \%$ yang berada pada kategori sangat tinggi sedangkan untuk kategori tinggi terdapat 15 siswa atau jika di presentasekan sebesar 37,50\%. Sedangkan pada siklus II untuk motivasi akhir didapatkan hasil untuk kategori sangat tinggi sebesar $87,50 \%$ dan untuk kategori tinggi terdapat $12,50 \%$. Hasil ini, menunjukkan bahwa motivasi belajar siswa kelas VII.1 sudah baik dan mengalami peningkatan setelah diterapkan pembelajaran kooperatif tipe Jigsaw. Hal tersebut didukung oleh persentase $0 \%$ dari kategori rendah dan sangat rendah. Hasil tersebut sesuai dengan target pencapaian yang diharapkan oleh peneliti 
104 Instructional Development Journal (IDJ), Vol. 1, No. 2, Desember 2018, Hal. 100-106

yaitu adanya peningkatan pada kategori tinggi dan sangat tinggi. Oleh karena itu, dapat dikatakan bahwa penelitian ini berhasil meningkatkan motivasi belajar siswa kelas VII.1 SMP Negeri 13 Pekanbaru.

Menurut Frederick (2007), "motivasi adalah perubahan energi dalam diri seseorang yang ditandai dengan timbulnya perasaan dan reaksi untuk mencapai tujuan”. Dalam penelitian ini motivasi siswa dibagi menjadi dua yaitu motivasi awal pada saat siswa belum menerima pembelajaran dengan menggunakan model pembelajaran kooperatif tipe Jigsaw dan motivasi akhir siswa setelah menerima pelajaran menggunakan pembelajaran kooperatif tipe Jigsaw.

\section{Hasil Belajar Ranah Kognitif}

Penelitian tindakan kelas ini dilaksanakan dalam dua siklus yaitu siklus I dan siklus II, yang mana di setiap akhir siklus selalu dilakukan tes akhir (post test) untuk mengukur hasil belajar ranah kognitif. Dalam pengambilan data ranah kognitif, hanya terdapat dua kali pengambilan yaitu pada akhir pertemuan siklus I dan akhir pertemuan siklus II yang dilakukan pada setiap akhir proses belajar mengajar di kelas. Pada tahap ini siswa diberikan lembar tes akhir (post test) yang berisi 6 soal uraian dengan waktu pengerjaan 20 menit. Tes akhir (post test) digunakan untuk mengetahui sejauh mana siswa memahami materi yang dipelajari menggunakan metode pembelajaran kooperatif tipe Jigsaw yang telah dilaksanakan. Berdasarkan analisis data hasil belajar siklus I kelas VII.1, terlihat skor ratarata siklus I adalah 68,75. Dengan nilai tertinggi adalah 89 dan nilai terendah adalah 45. Pada siklus ini terdapat 25 atau sebesar $62,50 \%$ siswa yang tidak tuntas KKM sedangkan jumlah siswa yang tuntas atau memenuhi KKM sebanyak 15 siswa atau jika dipersentasekan yaitu sebesar 37,50\%. Dengan demikian, nilai hasil belajar siswa siklus I masih belum mencapai target pencapaian awal yang telah ditentukan oleh peneliti.

Pada akhir siklus II siswa diberikan lembar soal tes akhir yang berisi lima soal uraian dengan waktu pengerjaan yaitu 20 menit. Tes akhir ini dilakukan untuk mengetahui seberapa jauh pemahaman siswa mengenai materi pencemaran dan kerusakan lingkungan yang telah diberikan oleh guru selama tindakan berlangsung. Berdasarkan hasil analisis data siklus II ranah kognitif dari kelas VII.1, diketahui sebanyak siswa belum mencapai KKM (Kriteria Ketuntasan Minimal) 7 siswa dengan persentasi 17,50\% sedangkan siswa yang mencapai KKM sebanyak 33 siswa dengan persentase 82,50\%. Dimana nilai tertinggi dalam siklus II yaitu 100 sedangkan nilai terendah adalah 40.Untuk rata-rata nilai kelas VII.1 yaitu 83,78 hasil ini termasuk sangat tinggi. Hal ini menunjukkan bahwa terjadi peningkatan aspek kognitif I (siklus I), pada aspek kognitif II (siklus II). Peningkatan ini menunjukkan tercapainya target yang diharapkan oleh peneliti.

Peningkatan hasil belajar aspek kognitif menunjukkan bahwa kegiatan yang dilakukan selama proses belajar-mengajar dengan model pembelajaran kooperatif tipe Jigsaw telah membantu siswa kelas VII.1 SMP Negeri 13 Pekanbaru untuk memahami materi tentang pencemaran dan kerusakan lingkungan. Terjadi peningkatan hasil belajar ranah kognitif siswa sesuai strategi pembelajaran tipe Jigsaw yang diungkapkan oleh Ardiyanto (2013) yaitu "untuk meningkatkan pemahaman siswa terhadap materi pembelajaran sehingga dapat meningkatkan nilai prestasi belajar". Hasil belajar dalam aspek kognitif yang meningkat juga dipengaruhi oleh beberapa faktor. Pertama adalah penggunaan metode dan media pembelajaran yang baik dalam hal ini dilakukan penerapan model pembelajaran kooperatif tipe Jigsaw yang membuat kegiatan belajar mengajar menjadi lebih menyenangkan karena melibatkan seluruh siswa dalam berdiskusi. Hal tersebut berdampak pada meningkatnya hasil belajar aspek kognitif yang terjadi selama tindakan berlangsung.

Faktor kedua adalah pemberian penghargaan berupa pujian dan hadiah. Menurut Fahturrohman dan Sutikno (2007) yang mengatakan bahwa "pemberian pujian dan hadiah kepada siswa yang berprestasi akan memacu siswa yang tidak berprestasi untuk mengejar atau bahkan mendapatkan prestasi yang lebih baik lagi dari pada anak yang berprestasi”. Pujian dan hadiah diberikan kepada siswa yang aktif bertanya, menanggapi hasil presentasi temannya, berani maju ke depan untuk mempresentasikan hasil diskusi kelompoknya dan kepada siswa yang memperoleh nilai tertinggi di kelas. Hal tersebut membawa dampak positif bagi siswa lainnya sehingga siswa saling berlomba-lomba mendapatkan nilai terbaik dengan meningkatkan kemampuan belajarnya. Faktor ketiga adalah kerjasama. Hal ini terlihat melalui relasi yang terjadi antar siswa selama berdiskusi. Pada saat melaksanakan kegiatan diskusi komunikasi antar siswa terjalin dengan baik sehingga siswa saling membantu 
dalam menjawab soal-soal yang terdapat pada kartu soal. Faktor keempat yaitu faktor yang berasal dari dalam diri (faktor intrinsik). Motivasi intrinsik tidak memerlukan rangsangan dari luar karena memang telah ada dalam diri individu sendiri, atau sejalan dengan kebutuhannya. Tinggi rendahnya kemampuan siswa dalam memahami materi yang dipelajari akan berpengaruh terhadap hasil belajar siswa terutama hasil belajar ranah kognitif.

Hubungan yang baik antara guru dan siswa juga menjadi pendukung meningkatnya hasil belajar aspek kognitif. Hal ini sesuai dengan apa yang diungkapkan oleh Slameto (2010) bahwa "hubungan guru dengan siswa merupakan faktor lain yang mendukung meningkatkan hasil belajar aspek kognitif”. Dalam penelitian ini hubungan guru dan siswa terlihat akrab sehingga siswa tidak sungkan ataupun malu ketika ingin bertanya atau meminta penjelasan dari guru untuk mengatasi kebingungan memahami pertanyaan yang terdapat pada kartu soal selama proses pembelajaran berlangsung. Secara umum, dapat dikatakan bahwa Penelitian Tindakan Kelas (PTK) yang dilaksanakan di kelas VII.1 SMP Negeri 13 Pekanbaru menggunakan pembelajaran kooperatif tipe Jigsaw pada materi pencemaran dan kerusakan lingkungan berhasil meningkatkan hasil belajar ranah kognitif siswa. Hal ini terbukti dari hasil tes akhir siklus I (post test I) yang mengalami peningkatan pada siklus II. Peningkatan tersebut dapat dilihat dari rata-rata kelas dan dari persentase siswa yang mencapai KKM.

\section{Hasil Belajar Ranah Afektif}

Hasil belajar ranah afektif diperoleh menggunakan lembar observasi yang telah disiapkan. Hal-hal yang diamati meliputi perhatian siswa terhadap penjelasan guru, antusias siswa ketika bergabung dalam kelompok asal dan ahli serta ketika menerima kartu soal, keseriusan siswa melaksanakan diskusi kelompok, keaktifan siswa mencari jawaban, mempresentasikan hasil diskusi dan menanggapi hasil presentasi kelompok lain serta menghargai pendapat teman. Data hasil belajar ranah afektif diperoleh melalui hasil observasi yang dilakukan oleh dua orang rekan mahasiswa selama tindakan berlangsung. Berikut adalah tabel hasil observasi yang diperoleh selama penelitian siklus I dan siklus II.

Berdasarkan analisa data diperoleh hasil belajar untuk ranah afektif mengalami peningkatan. Pada siklus I, terdapar $83 \%$ siswa berada pada kategori sangat tinggi dan $17 \%$ siswa berada pada kategori sedang. Sedangkan untuk kategori rendah tidak terdapat satupun siswa. Hal ini membuktikan bahwa hasil belajar ranah afektif sudah sangat baik. Pada siklus II dapat dikatakan bahwa hasil belajar ranah afektif siswa kelas VII.1 SMP Negeri 13 Pekanbaru mengalami peningkatan yang sangat besar antara siklus I dan siklus II. Untuk siklus II, siswa yang tergolong kategori tinggi sebanyak 100\%, dengan demikian dapat dikatakan bahwa tidak terdapat satupun siswa yang berada pada kategori sedang dan rendah. Hal ini menunjukkan bahwa hasil belajar ranah afektif siswa kelas VII.1 SMP Negeri 13 Pekanbaru sudah sangat baik.

Hasil belajar ranah afektif dalam penelitian ini diperoleh melalui lembar observasi yang telah di persiapkan oleh peneliti. Pengambilan data hasil belajar ranah afektif dilakukan oleh dua rekan mahasiswa yang bertindak sebagai observer sesuai dengan skor yang telah ditentukan. Observasi dilaksanakan untuk melihat dan mengamati sikap, aktivitas, antusias siswa dalam belajar, sikap ingin tahu, sikap percaya diri, serius, saling menghargai pendapat, semangat kerja sama dan sikap tanggung jawab siswa selama proses pembelajaran berlangsung.

\section{SIMPULAN DAN SARAN}

\section{Simpulan}

Berdasarkan pada penelitian yang telah dilakukan dapat disimpulkan bahwa penerapan metode pembelajaran kooperatif tipe Jigsaw pada siswa kelas VII.1 SMP Negeri 13 Pekanbaru dapat meningkatkan motivasi dan hasil belajar pada materi biologi pencemaran dan kerusakan lingkungan. Berdasarkan analisis data hasil penelitian, perolehan skor dari kuisioner motivasi belajar siswa sangat tinggi yaitu dari $63 \%$ menjadi $84 \%$ dengan kategori sangat tinggi. Sementara itu untuk hasil belajar aspek kognitif, skor rata-rata yang diperoleh pada siklus I adalah 68,75 dengan persentase ketuntasan KKM sebesar 37,50\% meningkat menjadi 83,78 dengan persentase ketuntasan KKM sebesar $80 \%$ pada siklus II. Sedangkan untuk hasil belajar ranah afektif juga sesuai dengan target pencapaian yang diharapkan yaitu adanya peningkatan pada kategori tinggi. 
106 Instructional Development Journal (IDJ), Vol. 1, No. 2, Desember 2018, Hal. 100-106

Dimana pada siklus I, 83\% siswa berada pada kategori tinggi dan 17\% dalam kategori sedang, sedangkan pada siklus II, 100\% siswa dalam kategori tinggi.

\section{Saran}

Berdasarkan simpulan hasil penelitian tersebut, penulis memberi saran sebagai berikut: 1) Penerapan metode Jigsaw membantu meningkatkan motivasi dan hasil belajar siswa sehingga dapat menjadi salah satu metode dalam proses pembelajaran di dalam kelas; 2) Penerapan metode Jigsaw membutuhkan instruksi yang jelas kepada siswa. Oleh karena itu, instruksi harus dipersiapkan sebaik dan sejelas mungkin sehingga peserta didik tidak mengalami kebingungan; 3) Media kartu soal yang digunakan dapat bervariatif sehingga siswa tidak bosan; dan 4) Model pembelajaran kooperatif tipe Jigsaw dapat diterapkan pada pembelajaran biologi karena dari hasil penelitian menunjukkan hasil yang positif.

\section{DAFTAR RUJUKAN}

Anggowo, R., dan A. Kokasih., 2007, Optimalisasi Media Pembelajaran. Jakarta: Grasindo.

Fathurrohman dan Sutikno., 2007, Strategi Belajar Mengajar. Bandung: PT. Refika Aditama

Fathurrohman, M., 2015, Model-model Pembelajaran Inovatif, Yogyakarta, ARRUZZ Media

Frederick, 2007, Motivasi Belajar. Yogyakarta : Andi Offset.

Instarini, 2011, Model Pembelajaran Inovatif, Referensi Guru dalam Menentukan Model Pembelajaran, Media persada, Medan.

Lie, Anita., 2002. Cooperative Learning. Jakarta : Gramedia Widiasarana Indonesia

Nana, S., dan Erliana, S., 2012, Kurikulum dan Pembelajaran Kompetensi, Bandung : PT. Refika Aditama.

Sardiman,A.M., 2005, Interaksi dan Motivasi Belajar Mengajar, Jakarta : PT. Raja Grafindo Persada.

Siska, F., 2013, Penerapan Model Pembelajaran Kooperatif Tipe Jigsaw Sebagai Upaya Meningkatkan Minat dan Hasil Belajar Biologi Materi Sistem Peredaran Darah Manusia pada Siswa Kelas VIII SMP Joannes

Sumarmi, Siti., 2005, Psikologi Belajar, Jakarta : PT. Raja Grafindo Persada.

Setyosari, Punaji., 2010,Metode Penelitian Pendidikan dan Pengembangannya, Jakarta : Kencana.

Slameto, 2010, Belajar dan Faktor-Faktor yang Mempengaruhi, Rineka Cipta, Jakarta

Slavin, R.,E., 2008, Cooperatif Learning: Theory, reaserch, and practice (penerjemah Nurulita), Nusa Media, Bandung.

Sudaryono, 2012, Dasar-dasar Evaluasi Pembelajaran, Graha Ilmu, Tangerang

Sudjana, N., 2009, Penelitian hasil Proses Belajar Mengajar, Remaja Rosdakarya, Bandung.

Sugiharto., Fathiyah, N.K., Setiawati., A.F., Harahap, F., Nurhayati, R.S., 2007, Psikologi Pendidikan, UNY Press, Yogyakarta

Suparno, P., 2010, Metode Penelitian Pendidikan Fisika, Universitas Sanata Dharma, Yogyakarta

Suprijono, Agus, 2009, Cooperative Learning, Teori dan PAIKEM., Pustaka Belajar, Yogyakarta.

Tetuko, A., 2014, Penerapan Model Pembelajaran Kooperatif Tipe Jigsaw sebagai Upaya Meningkatkan Motivasi dan Hasil Belajar Biologi Materi Pencemaran dan Kerusakan Lingkungan Kelas VIIB SMP Taman Dewasa Ibu Pawiyatan Yogyakarta, Skripsi, Universitas Sanata Dharma, Yogyakarta

Uno, B.H., 2007, Teori Motivasi dan Pengukurannya Analisis Bidang Pendidikan, Bumi Aksara, Jakarta

Winkel, W.S., 2009, Psikologi Pengajaran, Media Abadi, Yogyakarta

Yamin, M., 2012, Strategi Pembelajaran Berbasis Kompetensi, Jakarta: Gaung Persada Press. 